\title{
Chemical characterization of volatile organic compounds (VOCs) of [Lantana camara var. aculeata (L.) Moldenke] with polar solvent extractions
}

\author{
G. THANAVENDAN ${ }^{1 *}$, J. S. KENNEDY ${ }^{1}$ AND M. KANNAN ${ }^{2}$
}

${ }^{1}$ Department of Agricultural Entomology, Tamil Nadu Agricultural University, COIMBATORE (T.N.) INDIA

${ }^{2}$ Department of Nanoscience and Technology, Tamil Nadu Agricultural University, COIMBATORE (T.N.) INDIA

\section{ARITCLE INFO}

Received : 10.03 .2017

Revised : 07.08 .2017

Accepted : 20.08.2017

\section{KEY WORDS :}

Crude extracts, Leaf volatiles, Soxhlet extraction, Lantana plant, GC-MS
*Corresponding author:

Email : agrigtv@gmail.com

\section{ABSTRACT}

The present investigation was carried out to identify organic volatiles components present in Lantana leaves and found to exert biopesticidal-repellent action on many pests of horticultural crops. Volatile organic chemicals (VOCs) eluted from [Lantana camara var. aculeata (L.) Moldenke] was extracted ascrude oil and analysed by gas chromatography-mass spectrometry (GC-MS). A total of 10 to 15 volatile compounds present in ethanol and methanol extracts were identified. These compounds were found distributed in several chemical classes namely, alcohols, carbonyl compounds (ketones, aldehydes, and esters), fatty acids, terpenes, nitrogenous and sulphur compounds. Of these various classes of compounds identified,Phenol-2-methyl-5-(1,2,2trimethylcyclopentyl) - (S)-(CAS)-10.36 per cent and 2- (p-Methylphenyl) benzimidazole7.86 per cent constituted major groups accounting for ethanol and whereas sulphur compounds viz.,stigmast-5-en-3-ol, (3.beta.) 15.48 per cent, caryophyllene (7.63\%) and phenol having 14.96 per cent constituted major groups in methanol extracts.

How to view point the article : Thanavendan, G., Kennedy, J.S. and Kannan, M. (2017). Chemical characterization of volatile organic compounds (VOCs) of [Lantana camara var. aculeata (L.) moldenke] with polar solvent extractions. Internat. J. Plant Protec., 10(2) : 263-269, DOI : 10.15740/HAS/IJPP/10.2/263-269. 